\title{
Scottishness
}

\section{and Irishness in}

New Zealand

since 1840

ANGELA M C CARTHY

M. FOQARTY UMEOLN GOLF GEUH ROOH

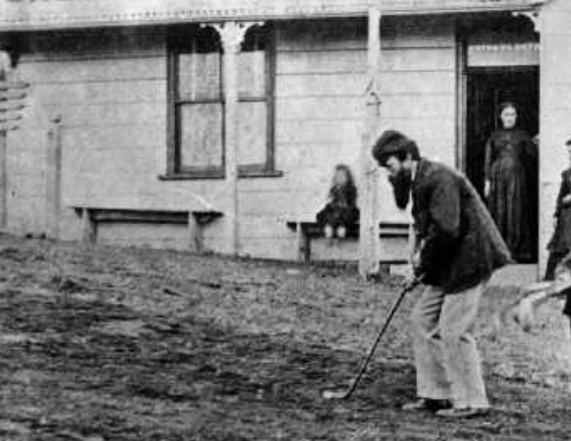

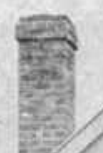
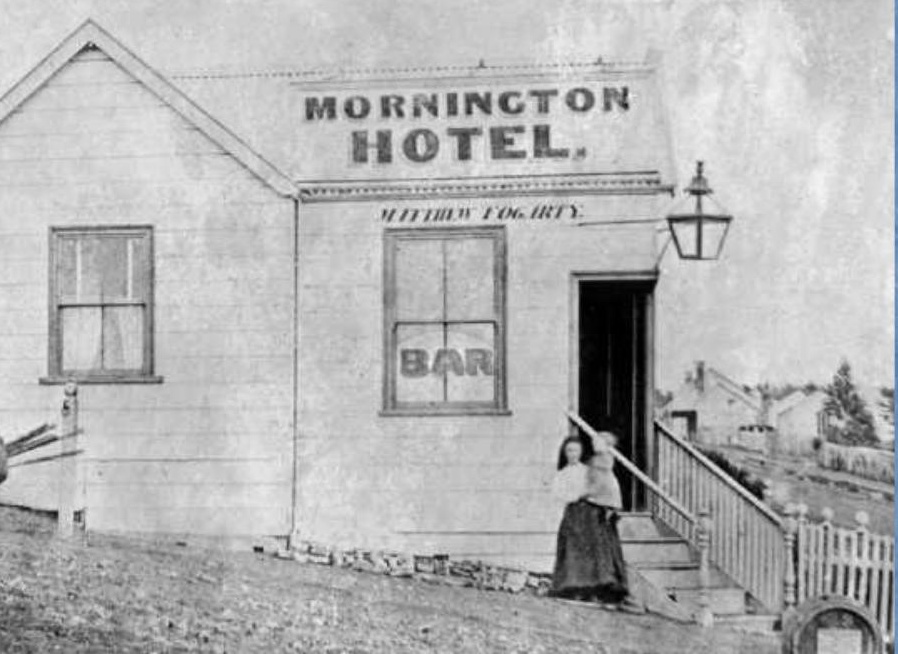


\section{IMPERIES IN-}

general editor John M. MacKenzie

When the 'Studies in Imperialism' series was founded more than twenty-five years ago, emphasis was laid upon the conviction that 'imperialism as a cultural phenomenon had as significant an effect on the dominant as on the subordinate societies'. With more than eighty books published, this remains the prime concern of the series.

Cross-disciplinary work has indeed appeared covering the full spectrum of cultural phenomena, as well as examining aspects of gender and sex, frontiers and law, science and the environment, language and literature, migration and patriotic societies, and much else. Moreover, the series has always wished to present comparative work on European and American imperialism, and particularly welcomes the submission of books in these areas. The fascination with imperialism, in all its aspects, shows no sign of abating, and this series will continue to lead the way in encouraging the widest possible range of studies in the field. 'Studies in Imperialism' is fully organic in its development, always seeking to be at the cutting edge, responding to the latest interests of scholars and the needs of this ever-expanding area of scholarship.

\section{Scottishness and Irishness in New Zealand since 1840}

\section{MANCHESTER 1824}

Manchester University Press 
SELECTED TITLES AVAILABLE IN THE SERIES

BORDERS AND CONFLICT IN SOUTH ASIA Lucy P. Chester SCOTLAND, THE CARIBBEAN AND THE ATLANTIC WORLD Douglas Hamilton MISSIONARIES AND THEIR MEDICINE David Hardiman EMIGRATION FROM SCOTLAND BETWEEN THE WARS Marjory Harper MUSEUMS AND EMPIRE John M. MacKenzie THE SCOTS IN SOUTH AFRICA John M. MacKenzie IRELAND, INDIA AND EMPIRE Kate O'Malley ENDING BRITISH RULE IN AFRICA Carol Polsgrove CHOCOLATE, WOMEN AND EMPIRE Emma Robertson 


\section{Scottishness and Irishness in New Zealand since 1840}

Angela McCarthy

MANCHESTER

UNIVERSITY PRESS

Manchester 
Copyright (C) Angela McCarthy 2011

The right of Angela McCarthy to be identified as the author of this work has been asserted by her in accordance with the Copyright, Designs and Patents Act 1988.

Published by MANCHESTER UNIVERSITY PRESS

ALTRINCHAM STREET, MANCHESTER M1 7JA, UK

www.manchesteruniversitypress.co.uk

British Library Cataloguing-in-Publication Data

A catalogue record for this book is available from the British Library

Library of Congress Cataloging-in-Publication Data applied for

ISBN 9780719077616 hardback

First published 2011

The publisher has no responsibility for the persistence or accuracy of URLs for any external or third-party internet websites referred to in this book, and does not guarantee that any content on such websites is, or will remain, accurate or appropriate.

Typeset in 10/12 Trump Mediaeval by Graphicraft Limited, Hong Kong 